Article

\title{
Gender Equality in Business Action: A Multi-Agent Change Management Approach
}

\author{
Leire Gartzia
}

Citation: Gartzia, L. Gender Equality in Business Action: A Multi-Agent Change Management Approach. Sustainability 2021, 13, 6209. https:/ / doi.org/10.3390/su13116209

Academic Editors: Mónica Segovia Pérez and Eva Cifre

Received: 2 March 2021

Accepted: 31 March 2021

Published: 31 May 2021

Publisher's Note: MDPI stays neutral with regard to jurisdictional claims in published maps and institutional affiliations.

Copyright: (C) 2021 by the author. Licensee MDPI, Basel, Switzerland. This article is an open access article distributed under the terms and conditions of the Creative Commons Attribution (CC BY) license (https:// creativecommons.org/licenses/by/ $4.0 /)$.
Deusto Business School, University of Deusto, 48007 Bilbao, Spain; Leire.gartzia@deusto.es

\begin{abstract}
Critical to social sustainability and organizations' growth, at present, is gender equality. Yet, egalitarian principles are difficult to apply in the practice, particularly in private firms. Acknowledging previous calls that research should respond to these concerns and support practitioners, we provide a theory-grounded conceptual framework to address change management in this field, aimed at providing applicable guidelines in the organizational practice. Integrating utilitarian and social justice perspectives about gender action, we call for multi-agent collaboration involving coordinated action from policymakers, private firms and gender experts. We provide an overview of how public policies and legislation guide organizational action by providing key statutory norms and procedures. We then address the relevance of organizational commitment and the alignment of gender goals with the organizational strategy and decision-making, involving managers. Finally, we underscore the benefits of implementing evidence-based action based on academic and consultancy collaboration. The implementation of these principles is illustrated with a multi-agent practice developed in the Basque Country (Spain) between gender equality change agents, suited to apply academic principles to real-world organizational practices. Recommendations for gender equality and corporate social action are provided.
\end{abstract}

Keywords: gender equality; sustainability; policy; Basque Country; change management

\section{Introduction}

Social and corporate sustainability has evolved to become central to corporate functioning, with suggestions that a firm's ability to integrate sustainability goals is critical to corporate success in modern economies [1]. The specific issue of how gender equality can become truly sustainable in business practices is particularly relevant, given the remaining resistance and concerns about women's limited progress within the workplace structure $[2,3]$. The challenge of promoting gender equality at work has been a fundamental priority internationally for social and corporate sustainability research and the various strategic plans of intergovernmental institutions such as the [4,5]. Despite the increasing effort that policymakers and corporate sustainability researchers are devoting to women's advancement at work, gender workplace discrimination is still present in all countries [4,6]. According to the Global Gender Gap Report published annually by the World Economic Forum, gender inequality is still evident even in the most egalitarian cultures. For instance, although Iceland represents the world's most egalitarian country according to the Global Gender Gap Report, in the last four years it still has an average wage gap of 0.727 (where 1 represents full equality). Similarly, Norway ranks 0.790 on the same index, with an average salary for similar work of $\$ 43,250$ USD for women and $\$ 59,495$ USD for men [7].

These resistances suggest that corporate sustainability efforts still face the challenge of finding more effective ways to ensure private firms' commitment to gender equality in the practice [8]. To a great extent, the prevalence of these resistances is due to private companies' generalized lack of genuine commitment towards social sustainability and gender equality in particular, as well as the wide disparities between gender equality actions, public policies and companies' strategic goals [8,9]. In many cases, resistance continues because of how 
regular implementations of gender equality take place in the workplace, where private firms and particularly top managers often adopt an "add-women-and-stir" approach in which companies simply enforce gender equality actions implemented in other companies without a critical appraisal [10]. Thus, gender equality plans are for most private firms an externally driven procedure that responds to legal obligations, rather than a strategic priority with serious commitments $[3,9,10]$.

Lacking a solid collaborative framework for the actual implementation of gender equality practices in organizations pushes private firms to mechanically implement general actions or to deliver the same social sustainability programs that have been implemented in other companies without a critical and strategic viewpoint. As a result, progress to achieve gender equality and reduce women's discrimination is very slow and vast amounts of disadvantage still accumulate over time in organizational practices [4]. Barriers to promote a critical gender perspective in organizational practices are also related to hidden norms and values about organizational processes and goals, which are often based on implicit expectations and stereotypes [3,11-15]. Consistent with traditional gender role expectations, effective management and decision-making are perceived as masculine characteristics [16]. These stereotypes create a double standard that not only generates distrust in women's abilities at work but also creates a stereotypically masculine image of organizational functioning that prevents organizational change from occurring.

The marked persistence of gender inequalities at work raises the question of how social actions should be further promoted and how to develop a science-based case for gender equality in the private sector that goes beyond simplistic views of gender [17]. If legally pronouncing obligations is not enough for necessary advancement, it is necessary that organizations, managers and human resource practitioners also develop a more profound conviction that gender equality can be a distinctive feature. With these concerns in mind, Grosser and Moon [8] underscored the complementary roles of social action and selfregulation of private companies in becoming inherently more engaged and concerned with social issues. Likewise, public agents such as the UK statutory body for tackling the issue of gender (i.e., the Equal Opportunities Commission; EOC) have argued that legislation should ensure "that the responsibility for gender equality is shared between individuals, employers and government" [8]. This emerging approach is particularly relevant if we take into account that social sustainability achievements are considerably slower among private firms. For instance, the gender pay gap is nearly $9 \%$ higher in the private sector than in the public sector [18]. Consistent with these concerns, developing creative institutional and managerial practices to foster gender equality that can be applied in any organizational setting is a critical goal.

Derived from and adding to these efforts, the theory and practices presented here pull together various organizational and societal challenges to develop a proposal of multi-agent cooperation aimed at providing new opportunities for social sustainability advancement, in particular gender equality. This approach combines academic research with real-life experiences that underscore the relevance of putting together public, managerial and technical support when implementing social sustainability policies in organizations. It is argued that having public policies that provide the relevant pressure and resources to motivate action towards gender equality is very important, combined with the corresponding conviction and action from firms themselves. We thus call for a new itinerary of change management in the field of gender equality that more holistically integrates legal prescriptions in the organizational strategy and managerial practice, generating strategic changes in how private firms approach the issue with coordinated efforts from key change agents. We advance towards these challenges by presenting a theoretically driven multi-agent distinctive framework based on a cooperative practice developed in the Basque Country. We argue that organizational change towards implementation of gender equality principles involves action from at least three relevant change agents: (1) public institutions, which provide the necessary regulations and institutional pressure, (2) organizational/firm change agents with managerial representation, which provide the necessary resources and planning, and 
(3) gender experts, who provide the necessary knowledge, conceptual frameworks and monitoring skills for action implementation.

To present this perspective, we first provide an overview of the political and cultural constraints of gender equality actions and describe how public policies and legislation influence the large context in which companies operate and develop social sustainability actions. Second, we analyze the organizational factors that influence the implementation of gender equality within firms, with a particular emphasis on change management research and the relevance of managerial support in organizational change processes. Finally, we examine how evidence-based management can provide the necessary conceptual and applied frameworks for appropriate implementation of gender equality change actions (see Figure 1 for a graphic display of these associations). Gender advancements are constrained by the gender gaps and stereotypes that prevail in a country, which are in turn linked to the agenda of government policies and discourses [9]. Thus, we enrich our theoretical development with the case of a Basque credit union set up within the Mondragon Cooperative Corporation [19], and examine its specificities by looking at statutory norms and procedures in the Basque context. Drawing from the case of this Basque private firm, we illustrate how a multi-agent approach can be incorporated in organizational practice, integrating utilitarian and social justice aims. We provide information that can be useful for evidence-based management and sustainability change agents implementing gender equality.

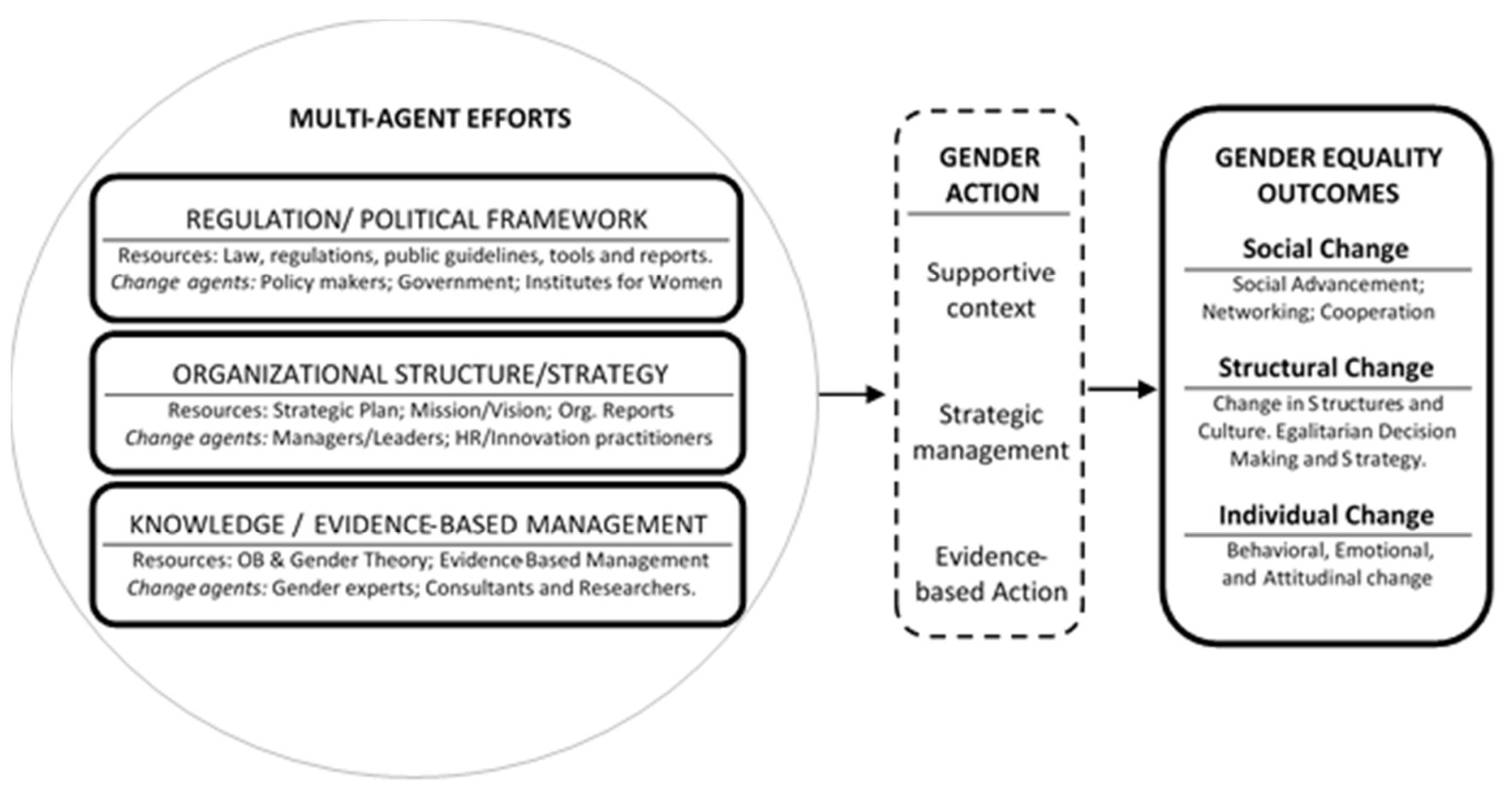

Figure 1. Multi-agent framework for gender action.

In the next sections, we describe the most important theoretical elements for understanding the role of these interrelated change agents (namely, public institutions, organizational practitioners and gender experts) and then provide the most relevant features of the Basque collaborative experience, including information about the actual interdependent roles of agents, development stages and action program contents in the practice. We argue that public support providing regulations, guidelines, networking and economic incentives are critical to the process while, at the same time, private firms should internally address how gender equality structures and progress can potentially have an impact on their functioning, with evidence-based support. 


\section{The Necessary Pressure: Gender Equality beyond the Organization}

Considering the impact of legislation and policies on organizations is critical for understanding how organizations make decisions and adapt their structures, processes and strategies to respond to the environment [20]. Indeed, because organizations operate in regulatory-intensive contexts, they are often attentive to these external pressures to redesign their activities and assess the overall impact of the legislation on their organizational practices. In the specific field of gender, and to overcome the slow advancement of women at work, many international norms and policies aimed at promoting women's rights in the workplace have been developed. In Europe, relevant programs and legislation have been developed to reduce gender stereotypes at work that have translated into specific arrangements, such as affirmative action programs for the advancement of women in decision-making in public and private organizations [21]. Legislation has provided a relevant background for the promotion of gender equality. For instance, in 2003, the Norwegian parliament established gender quotas for listed companies as stock exchange and state-owned companies, resulting in a drastic increase of female Norwegian board members from $6 \%$ in 2002 to $36 \%$ in 2008 [21]. These boardroom quota systems were implemented in other European countries such as Spain, France, Netherlands, Finland or Germany. Countries such as Iceland have gone a step further in promoting gender equality in organizations, imposing by law economic penalties to companies with more than 25 employees in which a wage gap between women and men exists [22].

Through such actions and laws, several countries have increased the numerical representation of women in relevant domains and have brought gender to the political and academic agenda. Accompanying specific regulations about gender equality, female representation in decision-making is also slowly yet steadily rising [6]. Policies and legislation are no doubt relevant for promoting these changes in organizations, which often occur through changes in individual attitudes. For instance, previous research examining the effects of the implementation of national legislation, such as smoke-free laws, has shown that bans are significantly and positively correlated with subsequent changes in behavior (e.g., lower smoking) and attitudes (e.g., support towards smoking bans) [23]. Laws, however, are not always translated into practice, particularly when they are based on general recommendations rather than specific regulations with procedures and sanctions when they are not fulfilled. Because gender equality actions and policies are often influenced by political ideologies, promoting actual changes in organizations is a difficult task.

Regulatory actions can assist progress towards gender equality by, for instance, underscoring the prevalence of implicit organizational practices and norms that are associated with stereotypically masculine characteristics and men [3,12-15,24]. Bringing gender issues to the surface may help overcome implicit images about successful management and decision-making, which are perceived as markedly masculine [16]. Additionally, generating formal procedures and actions that need to be implemented in organizations may help identify resistances against women as competent decision makers and may reduce stereotypically masculine images of organizational functioning $[2,25,26]$. European countries are often presented as examples of some of these advancements toward gender equality. In particular, research has underscored how rapidly changing European countries such as Spain, which quickly reorganized from a dictatorial regime to a democracy, have made notorious advancements in relation to women's roles at work and beyond, which can be taken as a reference for other countries $[27,28]$.

From a regulatory perspective, a major milestone of public gender policy in Spain at a national level was the creation in 1983 of the Institute for Women, a national agency independent from the Spanish government for implementing public policies on gender equality. This institutional body developed very quickly, providing specific resources and regulations for the implementation of gender equality in organizations, such as the Law on the Effective Equality between Women and Men (2007), which represents the compromise of the government in combatting stereotypes and all remaining manifestations of gender discrimination in both public and private organizations. In fact, this public 
agency reached the level of other advanced democracies in terms of goals and budget within only ten years of its creation [27]. Despite legislation, many inequalities between male and female Spanish employees and managers remain. Contrasting the Gender Equality Act of 2007, which recommended reaching a percentage of $40 \%$ of women in decision-making positions by 2015 , only $27.5 \%$ of women hold top managerial positions in listed Spanish companies and less than $16 \%$ in senior management [29]. Therefore, additional regulations are taking place, including obligations to register and periodically review gender equality plans and their implementation and to make information about salary gaps available (2019 and 2021 Legislative Decrees). Taken together, these statistics suggest that, although many inequalities remain internationally and in European countries with strong public commitments to gender equality, legislative efforts need to persist with the challenge of finding more effective ways of combining political support with private firms' self-regulation and actual commitment to the topic [8]. These regulatory efforts need to include specific goals and procedures about how to improve gender equality and the participation of women, in order to provide resources that are useful and can be applied in organizational practices. In the next section, some of these procedures and implementation resources are presented in more detail looking at the specificities of the Basque regulatory context.

\section{Public Support in the Organizational Practice: The Case of the Basque Institute for Women}

Gender equality is constrained by societal, economic and political factors that are at the same time shaped by the gender gaps and stereotypes that prevail in a country [9]. Thus, looking at the particular specificities of a context in terms of gender regulations and norms is important. In the Basque Country, an autonomous community in the northern region of Spain with a larger degree of autonomy and its own government, public policies that regulate gender equality have been particularly active. With exemplary rankings in several social metrics, including the eighth position in the world in the Human Development Index ( 0.915 out of 1$)$, second in productivity per employee ( $25 \%$ higher than the EU average) and eighth in income per capita in the European Union (30\% higher than the EU average), the Basque Country comes in front of most European Union members in the Gender Equality Index (GEI), a European composite indicator based on the EU policy framework that measures gender equality across European countries [30,31]. For instance, in 2019, the Basque government announced a pioneering law in the international agenda that equalized the length of leave between mothers and fathers, covering 16 weeks of paid leave through a non-transferable, fully paid paternity grant for men in all companies. Consistent with these regulations and achievements, the Basque Country occupies a leading position (before Spain) in the general ranking of countries' gender equality scores, as shown in several studies and European reports [30].

A noteworthy historical achievement in the Basque Country was the creation of the Basque Institute for Women (Emakunde) in 1988. This autonomous body of the Basque Government obtained in 2015 the first United Nations Public Service Award recognizing its excellence in the promotion of gender equality. This public institute was created to design, promote, advise on, coordinate and evaluate gender equality policies and raise awareness about gender inequalities in the Basque Autonomous Community. Importantly, although the most important area of activity of this public body involves action within public administrations and the implementation of gender-mainstreaming measures in all public policies, the promotion of gender equality in private companies has also been a priority. A relevant legal landmark was the 4/2005 Act for Equal Opportunity Between Women and Men, which required the creation and application by law a gender impact assessment and a gender equality plan to all public and private companies with more than 250 employees - currently 50 . These actions are required to be revised periodically by a nominated committee in the entity responsible for the implementation, monitoring and evaluation of the plan, including specific measures for the actual advancement of women that respond to the weaknesses captured in the most recent gender impact assessment in 
the firm. A summary of the most important elements included in these actions is presented in Table 1.

Table 1. Usual content of gender equality assessments reported by Basque companies (regulatory framework).

\begin{tabular}{|c|c|}
\hline Category & Items \\
\hline Features of the organization & $\begin{array}{ll}\text { 1. } & \text { Sector. } \\
\text { 2. } & \text { Size. } \\
\text { 3. } & \text { Organizational Structure. } \\
\text { 4. } & \text { Culture. } \\
\text { 5. } & \text { Objectives. }\end{array}$ \\
\hline Features of the workforce & $\begin{array}{l}\text { 1. Number of men and women. } \\
\text { 2. } \quad \text { Age (by sex). } \\
\text { 3. Educational attainment (by sex). } \\
\text { 4. } \\
\text { 5rofessional category (by sex and educational attainment). } \\
\text { 6. Type of contract (by sex). } \\
\text { 7. }\end{array}$ \\
\hline \multirow{6}{*}{$\begin{array}{l}\text { Human resources } \\
\text { management }\end{array}$} & $\begin{array}{l}\text { Hiring process: } \\
\text { 1. Recruitment channels. } \\
\text { 2. Sexist language in job offers. } \\
\text { 3. } \quad \text { Selection criteria. } \\
\text { 4. } \quad \text { Composition of the hiring team (by sex). } \\
\text { 5. Type and content of selection tests. }\end{array}$ \\
\hline & $\begin{array}{l}\text { Training: } \\
\text { 1. Hours dedicated to training (by sex). } \\
\text { 2. Training needs of the workforce (by sex). } \\
\text { 3. Access conditions to training courses. } \\
\text { 4. } \quad \text { Facilities for making training compatible with family life. }\end{array}$ \\
\hline & Career development: \\
\hline & $\begin{array}{l}\text { 1. } \quad \text { People promoted (by sex). } \\
\text { 2. Future previsions of promotion. } \\
\text { 3. Criteria to plan future career development. } \\
\text { 4. Composition of the team in charge of promotions. } \\
\text { 5. Mechanisms to encourage women's promotion. }\end{array}$ \\
\hline & Wage policy: \\
\hline & $\begin{array}{l}\text { 1. Mean salary (by sex). } \\
\text { 2. Salary level (by sex). } \\
\text { 3. } \quad \text { Criteria to decide wage increases. } \\
\text { 4. } \quad \text { Relation between salary, capacities and qualification. }\end{array}$ \\
\hline $\begin{array}{l}\text { Personnel opinions and } \\
\text { attitudes }\end{array}$ & $\begin{array}{l}\text { 1. Personal needs and expectations. } \\
\text { 2. Personal opinion about the role of women and men. } \\
\text { 3. Attitude towards equality of opportunities between women } \\
\text { and men's policies. }\end{array}$ \\
\hline Conclusions & $\begin{array}{l}\text { 1. Concerns and challenges. } \\
\text { 2. Proposals. }\end{array}$ \\
\hline
\end{tabular}

As shown in Table 1, the gender equality assessment mandated by the Basque government to private companies is required to include: general features of the organization; sex-disaggregated statistics and features of the workforce; facts about human resources management and employees' subjective considerations about the situation of women; and gender equality policies in the company. It is emphasized that gender impact assessments reflect a realistic picture of the situation and allow defining organizational policies that can potentially lead to change. Following these assessments, gender equality plans are 
developed to incorporate specific proposals of improvement, which have to be shared with employees. Importantly, the Basque Institute for Women has played a critical role in promoting and facilitating the execution of gender impact assessments and plans within this framework. Consistent with previous calls to combine public and private efforts as a way of promoting gender equality in organizations [8], the Basque statutory process emphasizes specific actions and provides the general background for private companies' greater commitment towards gender equality.

According to the European Institute for Gender Equality (EIGE), the Basque public system has four particularly remarkable strengths that may serve as a referent for other countries implementing gender equality regulations: the requirement by law to carry out the gender equality assessments; the involvement of all those people who devise and introduce policies and laws; the availability of training, guidance, and consultancy resources; and the provided technical advice and follow-up from gender equality units [32]. Acknowledging the relevance of providing quality consultancy on gender matters and facilitating a rigorous implementation of gender equality plans, the Basque Institute for Women also elaborates guidance resources and has developed a gender management certification system for consulting companies who want to provide quality guidance and tools for companies implementing gender equality actions. Through this function, the Institute sets out the formal standards through which private firms can get support to promote gender equality, providing the criteria for a gender-based assessment and management system of certified consulting firms. These consulting companies provide training, advising and consultancy in gender equality and human resources to private firms interested in implementing gender equality. Importantly, subsidies are granted to organizations that rely on one of the certified consultancy firms to get advice and develop their gender impact assessment and equality plan.

Aside from these incentives, the Basque Institute for Women has taken a leadership role in inspiring symbolic actions to foster equality policies in organizations, such as the granting of the official distinction "Entity Collaborating in Equality". This distinction is provided to companies with explicit commitment and investments in guaranteeing equal treatment of women and men and monitor implemented actions every two years. Adding to these actions, the Institute has created a network of collaborating entities that serves to facilitate cooperation and mutual learning of good practices (described at https:/ /www.emakunde.euskadi.eus/u72-home/es/, accessed on 19 February 2021), as well as specific actions in relation to challenges of masculine roles in the gender system (see Gizonduz project, in [33]). With this background, the Basque Country represents an interesting example of positive political and cultural influences within the larger context in which companies operate. These public actions have likewise laid the foundations for critical appraisals about gender equality in organizations and the development of more innovative gender-oriented practices in Basque private firms. In the next section, we present in more detail the specific role of private firms and organizations, followed by the specific example of a Basque company involved in these institutional actions.

\section{The Necessary Management: Firms' Structural Involvement}

Gender equality institutional policies and the growing pressures to improve women's situation at work are undoubtedly change drivers for organizations. In the change management literature, the concept of a change driver refers to whatever creates the desire or need for change in a given organization [34], including leadership, regulations or laws. Acknowledging the relevant role of legislative action presented above, environmental drivers are not enough to ensure the successful implementation of a change initiative per se. Indeed, organizational change research suggests that change initiatives fail very often, even when they are environmentally driven, particularly when it is not properly planned, organized, directed and controlled within the organization [35]. Because the promotion of gender equality in any given work context involves changes at many levels (e.g., organizational structures, interpersonal dynamics or individual values), understanding organizational 
dynamics, inertia and power is a critical factor to successfully introduce change from a gender perspective.

Looking at change management theory and practice, there is evidence that appropriate management and leadership are key to successful change, followed by corporate values and communication [36,37]. In particular, the change management literature has long acknowledged how effective strategies for change involve creating a guiding coalition where a group of people with enough power to lead the change are involved and work together as a team [35]. In relation to this, organizational change often involves transformation, not only in how an organization functions but also in who leaders are or how resources are allocated. Thus, a critical element in changing corporate policies and practices is managerial support. For instance, change efforts often fail because they lack the necessary time, budget and resources from decision-making bodies in the firm [37]. Because individuals are by nature resistant to change, change efforts require managerial efforts that ensure the necessary effort, resources and budget to gender equality actions.

Drawing from this perspective, the gender at work literature has acknowledged how managerial implication and support are critical for the successful implementation of gender equality actions. For instance, the European Institute for Gender Equality (EIGE; https:/ / eige.europa.eu/, accessed on 19 February 2021)—an autonomous body of the European Union aimed at strengthening the promotion of gender equality in organizational practices with an action toolbox to promote institutional change in research and higher education institutions-has explicitly addressed how managers have a critical role in the implementation of gender equality plans. In their "Gender Equality in Academia and Research (GEAR) action toolbox" to develop gender equality, it is addressed how setting up a gender equality plan that is fully and publicly supported by senior managers and leaders is critical to give visibility to gender equality goals and ensure a collective understanding of gender-related work [28] (see also https: / / gearingroles.eu/, accessed on 19 February 2021). This is important for publicly supporting the gender equality actions that are taking place, ensuring the practical implementation of the measures, procedures and activities listed in the gender equality plan and instructing the relevant units to provide information to monitor the implementation and progress towards gender equality [38]. Collectively, these facts suggest that managers and leaders in charge of the day-to-day management and resources of the organization are key change agents in the process of promoting gender equality within the firm by providing the necessary resources, visibility and support.

Managerial support is a critical element in organizational change processes, and acceptance of the change process at all organizational levels also requires translating such structural support into emotional, cognitive and behavioral transformations through shared work and support of a common purpose. These more emotional and attitudinal patterns of change require commitment from people at different levels in the organization, making them able to feel and do what is necessary for the change process. Following the change management approach of Gill [37], the concept of empowerment is key to understanding this process and how leaders need to give people the power and motivation to change. Following Kotter [35], Gill explained that "empowering people for action in part entails getting rid of obstacles to change, removing or changing systems or structures that undermine the vision, and encouraging risk-taking, new ideas and innovative activities" [37] (p. 315). Showing the logic behind the change and communicating its relevance is therefore key in overcoming resistance to change in these organizational processes of transformation in order to motivate and inspire employees. Likewise, building support and promoting participation from different organizational agents lessens resistance towards the change, facilitating the transition to new desired states [39]. In this process, organizational leaders need to work together with other change agents in the organizational structure and be credible and committed to the domain of change, expressing confidence in people's ability to achieve the desired goal. For instance, managers and leaders can frame the change action as an organizational priority that is publicly supported by them, giving visibility to the 
relevance of promoting such action $[37,39]$. This is to develop a collective, shared vision about the importance of the change, framing it as an organizational priority.

\section{Managerial Support in the Organizational Practice: The Case of a Cooperative Basque Firm}

Derived from the above-mentioned institutional role of the Basque Institute for Women in supporting gender equality in organizational practices, several Basque organizations and private firms have in recent years shown their commitment and investments to promote women's advancement at work, granting the institutional distinction of the Basque government as an "Entity Collaborating in Equality" (described at http:/ / www.emakunde.euskadi.eus, accessed on 19 February 2021). In this section, we provide the exemplary case of one of these private firms, LABORAL Kutxa, a Basque credit union founded in 1959 under the Mondragon group, a world leader referent in cooperativism with more than 150 businesses and 100 independent cooperatives in the Basque Country. As part of this cooperative network, LABORAL Kutxa has a participatory structure following principles of social justice, being the first credit union in the Basque Country and the third largest in Spain, with approximately 1,300,000 clients and $2500 \mathrm{em}$ ployees. This financial company was a pioneering entity in the development of active policies in support of equality, becoming the first company that obtained the institutional award for the promotion of gender equality provided by the Basque Institute for Women in 1997.

Importantly, unlike investor-owned firms, employees in cooperatives own the corporation and have an active function in management and decision-making. Consistent with this participatory structure, cooperatives are often characterized by displaying more democratic methods in decision-making and strongly basing managerial decisions on ethical principles as a core value [19]. In the field of gender equality, these firms under the cooperative Mondragon group have stood out with actions such as the creation in 1969 of a cooperative (i.e., Auzo-Lagun) owned only by women, who were allowed to work part-time in a time in which women used to leave their job when they got married (see [27] for a review of gender policies in Spain). The promotion of fair, equitable and supportive workplaces are thus relevant elements in this groups' historical vision and mission (described at https: / / www.mondragon-corporation.com, accessed on 19 February 2021). Following this structure and contrasting other Basque companies, this credit union assigned specific economic resources to gender actions, with specific annual budgets for the implementation of equality policies. For instance, during the 2016-2018 period in which a specific program of empowerment was designed, the firm invested 28,901.81 euros for program design during 2016, 32,753.82 euros for consulting and academic support during 2017 and 62,992.83 euros in 2018 with an increased budget for the implementation following a grant obtained from a public Basque institution (i.e., the Provincial Council of Gipuzkoa).

In addition to allocating resources, the company created a stable and active organizational structure for the development of gender equality policies consistent with the structural and managerial principles described in Table 2. This structure included strong managerial support (with the active participation of the Director of Social Management in all gender equality meetings and actions) and the creation of a specific job position (a Gender Equality Coordinator) for the coordination of equality plans. People in relevant decision-making positions also represent an important part of the Gender Equality Committee, a group of 13 employees assembled in 2011 to actively participate in the elaboration and monitoring of gender equality actions following the general guidelines of the Basque Institute for Women. Members in this committee meet at least three times per year and include managers with relevant positions in the company (e.g., the Director of Social Management, the Director of Communication and the Legal Counsel, among others). Given that effective implementation of gender equality requires active participation and involvement of top management $[40,41]$, these are relevant conditions for a company's commitment to gender equality. 
Table 2. Content and phases of structural change processes towards gender equality (strategic change management).

\begin{tabular}{|c|c|c|}
\hline Agents involved & $\begin{array}{l}5 . \\
6 . \\
7 . \\
8 .\end{array}$ & $\begin{array}{l}\text { Board of Directors, providing awareness, legitimacy and visibility to the topic. } \\
\text { HR Department, in the field of execution and integration of the plan within the company's } \\
\text { processes. } \\
\text { Legal representatives of the workforce, making proposals and participating in training and } \\
\text { awareness. } \\
\text { Permanent Equality Committee, in charge of communication and raising awareness among } \\
\text { employees. } \\
\text { Workforce, making proposals. } \\
\text { Experts (internal/consultancy firm/researchers-academics), providing technical assistance. } \\
\text { Communication Department, informing about the actions put into practice. } \\
\text { Gender Equality organisms/public institutions, providing support and encouraging action. }\end{array}$ \\
\hline Phases & $\begin{array}{l}2 . \\
3 . \\
4 . \\
5 . \\
6 .\end{array}$ & $\begin{array}{l}\text { Commitment of the Board of Directors in writing a document and communication to the } \\
\text { workforce. } \\
\text { Creation of the Gender Equality Permanent Committee. } \\
\text { Initial diagnosis, with data collection and analysis data and presentation of } \\
\text { change/improvement areas. } \\
\text { Equality plan elaboration, based on the initial diagnosis and the resulting suggestions for } \\
\text { improvement. } \\
\text { Implementation and execution of the actions contained in the gender equality plan. } \\
\text { Evaluation of the results, assessing the degree of compliance with each action and identification } \\
\text { of new goals. }\end{array}$ \\
\hline $\begin{array}{l}\text { Content of the } \\
\text { Gender Equality Plan }\end{array}$ & $\begin{array}{l}4 . \\
5 . \\
6 . \\
7 . \\
8 . \\
9 .\end{array}$ & $\begin{array}{l}\text { Diagnosis results. } \\
\text { Objectives. } \\
\text { Actions to be implemented in different areas, including selection, promotion, work-time } \\
\text { planning and work-life balance, work conditions, training, labor risks, representativeness, } \\
\text { communication, language and representation of women in images, women at risk of exclusion, } \\
\text { sexual and sexist harassment, organizational culture. } \\
\text { Evaluation system in relation to the results, as well as the process and the expected impact in } \\
\text { the organization. } \\
\text { Schedule. } \\
\text { Budget. } \\
\text { Participation of the legal representatives of the workforce. } \\
\text { Composition of the Equality Permanent Committee. } \\
\text { Change agent responsible for the plan. }\end{array}$ \\
\hline
\end{tabular}

During the different phases of the project, internal communication occurs between the agents

Communication involved in the process, focusing on reinforcing companies' commitment in terms of gender equality. It is also important to manage external communication processes, projecting the acquired compromise in the field of gender equality.

\begin{tabular}{ll}
\hline Training & Specific training actions covering stereotypes, equal opportunities and gender equality. \\
\hline Monitoring & Tracking of the implementation of different actions during the execution phase. \\
\hline
\end{tabular}

Importantly, gender equality was also on the company's managerial agenda by integrating gender equality plans into the organizational strategy and the annual management plans, as well as by addressing gender equality issues on managerial meetings. As a consequence, three gender equality plans were produced and implemented, aimed at raising employees' awareness and improving organizational functioning from a gender perspective following Table 2 principles. These plans were accompanied by the creation of a bulletin summarizing the actions carried out by the entity in relation to equality and disseminated every six months; an online forum on the company intranet aimed at encouraging people to share opinions about gender issues; a guide about inclusive communication; and awareness-raising video sketches performed by employees representing situations of inequality that can occur at work and in the interaction with customers (watch the video at [42]). Actions aimed at having an impact outside the organization were been 
developed, including assessments of customers' perceptions about gender equality in the company or awareness campaigns in the International Women's Day or the International Day for the Elimination of Violence Against Women, among others.

Conceiving gender equality as a relevant resource for organizational functioning was particularly relevant to develop a greater commitment to gender equality by managers and change agents in the organizational practice. In particular, several actions were developed to integrate gender equality goals into strategic change actions. For instance, LABORAL Kutxa engaged in a process of redefining leadership competencies and core organizational and cultural values from a gender perspective. Acknowledging the persistent associations between stereotypically masculine roles and leadership functions [16], the company got involved in several actions aimed at redefining the leadership styles of both men and women in management positions to improve performance, with a special focus on promoting leadership behaviors and traits that were in line with both gender equality and the company's desired organizational culture (e.g., empathy, active listening, flexibility and communication skills). Through these strategy-centered actions, the company aimed to more clearly frame gender issues as a relevant resource for organizational functioning and thus become more engaged with the actual promotion of gender equality.

These efforts to integrate gender equality in organizational goals allowed better alignment with the organizational strategy. From a managerial perspective, incorporating this utilitarian approach is important because it allows a better implementation of change efforts $[35,43-45]$. Indeed, the basic tension that underlies many attempts to incorporate gender equality actions in organizational practices is that it is often necessary to convince decision makers and key change agents in the first place because they can ultimately promote transformations at deeper levels of the organizational structure and dynamics. In relation to this, the change management literature has also shown that even these apparently minor processes of awareness raising (which implicitly occur during the implementation of change actions involving managers), can ultimately serve to redefine organizational goals and processes (see [46]). Therefore, these incremental transformations of gender awareness that involve changing managerial ideals and responses to more "androgynous" and less masculine definitions of leadership have the potential to accumulate and translate into more revolutionary and substantial transformations that can alter the whole organizational structure and strategy from a gender perspective.

\section{The Necessary Expertise: Evidence-Based Action}

The intellectual/cognitive dimension of change management is critical to avoid failure in any intervention or transformation process, especially in situations of rapid organizational change [37]. Thus, effectively leading change requires intellectual and conceptualization abilities to properly set objectives and identity resistances. This approach is connected to the idea that scientific knowledge has historically led to better decision-making and served to inform economic, social and political practices in diverse knowledge fields. Indeed, scientific evidence in social sciences and, in particular, in management offers reliable evidence of relationships and cause-and-effect associations, which can, in turn, translate into applied actions such as successful intervention or training programs [41]. For instance, management research has shown that certain factors associated with leadership traits and styles lead to higher on-the-job performance, suggesting specific organizational actions that can aid selection decisions and training programs (e.g., [26,39,41]).

Consistent with this idea, evidence-based management [41] establishes that managerial decisions should be based on the latest available scientific evidence in order to develop more effective organizational practices. According to evidence-based teaching, translating scientific evidence into practice requires that practitioners and managers "first learn what it says and then how to apply it" [41]. Consistent with this principle, organizational actions would ideally have the first stage of general conceptualizations that can be easily but accurately understood at different organizational levels, followed by actions aimed at translating concepts into specific implementation ideas. In contrast, focusing training 
programs on an extended review of organizational behavior theories has been argued to be problematic given employees' and managers' heavy workloads. Instead, given the complexities of change management research, it has been suggested that "fundamental to any shift toward evidence-based management education [ ... ] is a focus on core principles underlying the behavior in and of organizations that the best available research supports" [41].

In the scientific literature, there are examples of successful implementations of programs in other areas, such as the so-called participatory intervention model $[24,47,48]$. This approach involves the active involvement of participants in understanding scientific evidence and subsequently designing interventions. This model also requires that theoretical issues are jointly addressed and understood at every phase of a training process. Subsequent action plans are then developed through the active contribution of participants. Importantly, in these programs, participation is not limited to disclosing certain information or requesting opinions but rather aimed at critically appraising issues that are raised and collectively designing action plans that can be feasible in practice, which requires a combination of scientific and applied skills. With this idea in mind, gender equality programs in organizations should incorporate a scientific approach based on an evidence-based but simplified model of gender research findings.

When implementing changes in organizations, it is also important to have a scientific methodology for managing and monitoring planned change [49]. This approach of action research involves asking for feedback about the actions being implemented, as well as an initial diagnosis and analysis of the situation that examines the general patterns, problems and possible actions in the organization. This assessment can be developed through interviews/surveys of employees and by asking relevant questions and looking at previous records, as well as a final evaluation of the action plan's effectiveness, using as a benchmark the data that was initially gathered [50]. Data gathered after sessions also serve to learn from possible mistakes and make modifications as needed, enabling improvement of the program structure, as well as the monitoring of progress towards program goals. According to Rousseau and McCarthy [41], the formulation of research questions is also a critical principle for evidence-based teaching, being necessary to diagnose underlying factors related to decisions made within an intervention program. Consistent with this approach, gender equality actions are encouraged to involve systematic and reliable evaluation systems [38].

The issue of using scientifically valid findings and conclusions rather than dishonestly focusing on a few studies that favor one's ideological position is particularly important in relation to gender. As Eagly [51] noted, advocates like policymakers or consultants often "fix on particular studies that support their favored policy positions, with little concern for how typical, generalizable, or scientifically valid their findings are" (p. 213). This general tendency of advocates and policymakers to speak in terms of the main effects of diversity (e.g., in line with the idea that gender diversity produces all types of positive outcomes in organizations) can be troubling. For instance, whereas the overall message from gender research is that effects of diversity are on the average almost null, with positive and negative effects being equally likely, advocates often "sell" a simple business case message that simplifies the phenomenon and omits negative and null effects [51]. As a consequence of these contrasting interests, scholars and practitioners often approach organizational interventions separately. This separation can be problematic because gender consultancy firms are in a unique position to serve as a bridge to develop partnerships between private companies and gender researchers that respond to both utilitarian and social goals. However, these collaborations are rare, due to the general inherent conflicts of knowledge usage between consultants and academics [52].

Consultancy firms specializing in gender issues are in a unique position to implement public regulations in the organizational practice and mediate between private firms and gender researchers. These collaborations could become more common if conflicts of knowledge usage in their approaches would be acknowledged [51,52]. As Alvesson puts it, 
"subjective orientations and person-bound talents [ ... ] are more significant than formal knowledge and specialized work role experiences and skills in most consultancy organizations" [52] (p. 1005). The scholarly impact that produces greater engagement in reflexive conversations between academic researchers and practitioners has the potential to change business practices and have an impact on government policy [53]. However, particularly on politically charged issues like gender equality actions and policies, practitioners are frequently influenced by ideological views and perspectives, making it more difficult to objectively apply social scientific data [51]. As a consequence of these contrasting interests, scholars and practitioners often approach organizational interventions separately. Thus, developing specific guidelines for the advancement of collaboration between academics and practitioners is a critical challenge to reaching gender equality in organizational practice.

Importantly, advocacy and policy goals do not justify misrepresenting science. Yet, a completely unbiased focus may also be seen as both impossible and undesirable. Research findings are naturally subject to problems including issues of causality, endogeneity and generalizability, with even the most sophisticated research methods such as meta-analyses being subject to bias [54]. Additionally-and linked to the previous consideration-it would be an obvious violation of democratic principles to purportedly underscore research findings associated, for instance, with the superiority of certain social groups (e.g., men, white) over others (e.g., women, discriminated racial groups). Consequently, one could argue that it is reasonable that organizational practitioners and policymakers offer reasoned, shared and democratic logics that at the same time are scientifically valid and do not violate the true findings. Likewise, advocates should become more "honest" and keep scientific knowledge at the forefront, reflecting in their discourse the complexities found in previous research [51].

\section{Gender Expertise in the Organizational Practice: Academic and Consultancy Collaboration}

In the process of developing a gender equality diagnosis and action plan in firms, the support of gender experts is explicitly encouraged in the Basque regulatory system. The Basque Institute for Women provides a formal list of approved consultants for the provision of technical assistance in gender equality. Consistent with LABORAL Kutxa's commitment to gender equality, for many years, gender equality actions were implemented in the company with the technical advice of one of these certified consultancy firms (i.e., a Basque consultancy under the Elhuyar Foundation, a Basque foundation aimed at socializing science and technology within the Basque society). This consulting firm had provided technical assistance in the field of gender equality to other public and private entities at different stages of gender equality actions (e.g., auditing and design, implementation and evaluation of gender equality plans), providing key support for the promotion of gender equality in the company. Resulting from these collaborations and commitment, LABORAL Kutxa had produced and implemented three gender equality plans. With the idea that scientific knowledge can clearly inform organizational practices and address the challenges of successfully implementing equality actions, in 2016, these firm widened their scope and approach by searching for additional academic support to supplement their actions, starting a collaboration with a research group at a Basque university aimed at developing research-based actions to be implemented in their actual organizational practices.

During the process of evidence-based implementation, several meetings were held between the gender equality agent, a human resources (HR) leader, and the two external gender experts (a consultant and a gender researcher). These meetings consisted of guided conversations aimed at defining actions, goals and evaluation and designing the general content of the action plan. After several meetings held during a two-month period, a series of actions and evaluation processes were designed. The program included actions aimed at gathering evidence about gender-related dimensions at different levels of analyses. These included, among others, women's subjective perceptions for career development and employees' perceptions of implicit leadership competencies in the organization, which 
were fully developed based on academic standards, psychometric properties and scientific analyses following academic standards for managing and monitoring planned change [49].

Four training participatory workshops were also developed, in which members of the above-mentioned Gender Equality Committee took part. A relevant principle of evidencebased teaching is to provide practitioners with a simplified version of cause-and-effect research findings that can be reflectively understood and memorized [41]. Therefore, the sessions included a simplified version of research findings through the lens of empowerment. Empowerment represents a theoretical concept that nicely serves to connect theory and practice by helping understand the connections between individual, social and organizational contexts. Although empowerment does not have an agreed-upon definition, it has generally been defined as "the connection between a sense of personal competence, a desire for and a willingness to take action in the public domain" [55]. Empowerment has also been addressed as "identification of personal issues, critical assessment of the social and historical precursors of these issues, and the implementation of social action plans to work towards overcoming these issues" [56]. Drawing from these definitions, the empowerment-distinctive concept provided a suitable conceptual framework to understand in practice the connections between individual, social and structural contexts, providing a useful scientific approach for the applied promotion of gender equality in the practices of the organization.

In an effort to simplify these streams of the empowerment literature and continue developing gender equality actions within the framework of LABORAL Kutxa's gender equality plans, we developed a specific training program organized around this overarching gender-related framework during 2017, which served to capture participants' attention and develop new action plans. This overarching concept of empowerment inherently includes the most important connections between individual, relational and structural influences, so this framework was found to be useful for advancing new reflections and specific action plans to further promote gender equality within the organization. Following the above-mentioned principle of evidence-based teaching aimed at translating scientific evidence into practice [41], the program included the first stage of general conceptualizations of three dimensions of empowerment that were followed by actions aimed at translating concepts into specific implementation ideas. The scientific program presented to participants derived from the management literature. The concept of empowerment nicely connected issues of change management (i.e., by capturing the necessary transformations in organizations from empowered employees at all levels, who are encouraged to adjust to new organizational structures) and gender equality (i.e., by capturing the necessary transformations in gendered identities and structures). Therefore, the concept of empowerment was a useful conceptual approach for organizing gender-related action.

The conceptual perspective of empowerment was used to refer to both contextual/socialstructural conditions that enable empowerment at work (i.e., empowering structures, policies and practices) and the psychological, more individual experience of empowerment (individuals' subjective reactions to such structures, policies and practices; see [57] for a review). For the latter, there was a particularly relevant focus on motivational processes of workers that involve individual cognition and attitudinal changes [58,59]. The individual dimension of empowerment was also particularly reflected in the concept of psychological empowerment, which focuses on individual thoughts and behaviors that favor perceptions of personal control and a proactive approach to one's life within a given context [55]. Having a psychological sense of community and mutual help has also been identified as a critical antecedent of empowerment in different domains [55,60-62], providing a useful approach during the implementation of the program to understand how individuals' shared participation in a community of interpersonal relations shape the connections between an individual and her/his achievements in the social context (i.e., the social/relational level).

Because a goal of our intervention was to design an organizational action plan that would lead to substantial changes in how the organization approached the three areas of empowerment (structural, individual and relational/social), the empowerment program 
was directed to a diverse group of people with some experience in gender equality issues and different levels of responsibility within the organization. This group included agents of the Gender Equality Committee with a representation of top-level, middle-level and low-level managers, regular employees and a gender equality agent, as well as the gender equality external consultant firm certified by the Basque Institute of Women. Consistent with research underscoring men's relevant role in reducing gender stereotypes and the prevalence of stereotypically masculine characteristics in organizations $[25,26]$, not only women but also men with different positions in the organization were involved in the program.

These workshops were spaced about one month apart and consisted of individual, pre-session readings of the concepts studied and four face-to-face sessions. After a general three-hour introductory session in which a gender scholar provided the most relevant concepts about the framework of empowerment, subsequent sessions were conducted in which each specific dimension of analysis (i.e., structural, individual and relational) was developed. Rather than superficially touching on many organizational behavior and gender research topics and theories, we focused on a few relevant concepts in each dimension of analysis. These presentations were then followed by individual and group reflections on how they might be transferable to day-to-day actions (see Appendices A and B).

This approach provided learners with a more practical experience directed at identifying specific actions in each domain. Previous research has shown that teaching managers to apply evidence-based programs involves not only the presentation of the theory but also exercises that develop theory into "actions, techniques, and practices the individual can reliably perform, such as translating work plans into appropriate goals in terms of specificity, content, and process" [41]. The principles of goal-setting theory also establish that challenging and specific goals set by the employee are the most effective motivators of performance [63]. Thus, our program emphasized that participating employees and managers could use it in their professional practice.

Importantly, the program also involved the necessary resources to translate knowledge into specific gender equality practices. These resources included a varied range of visual techniques to promote participatory decision-making (such as short evidence-based lectures that generated participants' reflection on potential applications and icebreakers or breakout group discussions based on the most relevant conceptual elements that were developed through group cards). Visual techniques with graphic summaries and stimuli expressed through drawings and symbols were also used. For instance, visual schemas that combined participants' suggestions of actions were drawn on a board in a summarized way and served as the basis for the action plan. These techniques allowed a more in-depth analysis of and reflection on the topics, leading to better assimilation and understanding of the concepts.

As a result of this process of analysis and reflection, an action plan was developed at the end of the program including change actions at a structural level (e.g., actions aimed at redefining leadership styles and promotion processes), individual level (e.g., assessment and action plans to change individual attitudes and behavior) and social/relational level (e.g., generation of online networks for opinion exchange and dissemination of the work in several networks). A summary of this action plan with specific stages and deadlines is presented in Appendix C. Making participants feel comfortable was important, so meetings were held in a relaxed work environment with time for reflective thinking and refreshments.

\section{Discussion}

Throughout this paper, we have underscored the challenges of integrating sustainability action from different agents involved in the process of promoting gender equality in organizations. On the one hand, we highlight the challenge of integrating political sustainability action with a private firm's interests. On the other hand, we call attention to the question of integrating scientifically valid findings with understandable summaries of gender knowledge that can satisfy firms' specific challenges if actions are to become 
truly sustainable. The current work suggests that a fundamental reconsideration of the interdependent role of corporate sustainability change agents in the domain of gender equality is both necessary and feasible. We presented the Basque Country as an interesting case of advancement that exemplifies a relevant framework of regional European gender policies $[27,30,31]$. In doing so, a distinctive feature in our approach is to underscore the challenge of public institutions developing new social sustainability initiatives aimed at supporting, monitoring and reporting progress in the promotion of gender equality in private companies. Underscoring the relevance of anti-discrimination legislation and public policy is a provocative addition to the traditional non-interventionistic approaches that are characteristic of some economically developed countries, but this has received rather limited attention in the literature thus far.

Importantly, our practice was based on basic and applied research grounded in gender studies and theory. It has been argued that managerial decisions should be based on the latest available scientific evidence in order to develop more effective organizational practices and inform social policy [41]. In the field of gender studies, a large pool of research literature has identified an important and complex array of individual, interpersonal and organizational obstacles that women face in organizations, making it difficult to suggest simplistic actions in which gender equality can be rapidly achieved. The lack of a solid framework for the actual implementation of gender equality in organizations pushes private firms to mechanically implement general sustainability actions prescribed by law or to deliver the same programs that have been implemented in other companies without a critical and strategic viewpoint.

Scientific evidence that can influence the organizational practice, and is aligned with institutional policy, has the potential to transform business practices and structures with a more solid set of principles. Yet, particularly in relation to ideologically charged social topics such as gender equality, objectively applying social scientific evidence is difficult in practice [51]. Additionally, public institutions, academics and organizational practitioners often address social sustainability change processes in isolation. In addition to these problems, collaborations between gender-sensitive consultants and gender scholars are limited [51,52]. A key contribution of the multi-agent, collaborative practice presented here is responding to these challenges and bringing together public institutions, scholars, consultants and management practitioners to the advancement of both scientific knowledge and individual and organizational development in social sustainability and gender equality.

Based on the idea that scientific knowledge can clearly inform organizational practices and corporate sustainability, we developed research-based actions to be implemented in organizations. Fostering social sustainability and gender policies that are based on science has been identified as the only route to facilitate progress in identifying the actual conditions under which gender constraints occur at work and develop evidence-based policy options [51]. We addressed these challenges through the lens of empowerment, a concept that nicely serves to understand the connections between the individual, social and organizational context. The empowerment approach is a particularly relevant concept in feminist theory and practice, and it is inherently linked to gaining power at different levels including individual, social, economic and political gains. Therefore, it provided a useful conceptual tool to integrate research findings with applicable sustainability actions in our cooperative program. Given women's remaining disempowerment and the problems they face in being valued in organizational practices, this approach is timely.

\subsection{Managerial Implications with Utilitarian Viewpoints}

One critical implication of the multi-agent-based organizational practice presented here is that it is critical to accord greater emphasis to sustainability frameworks and actions that allow for more complex integration of utilitarian and social justice aims. In contemporary organizations, the nature of work processes has increased the importance of stereotypically feminine characteristics that assist in promoting employees' participation and involvement in teamwork that can innovate to establish competitive advantages 
for organizations [2,25]. In this context, new definitions of management have emerged with greater relevance of people-oriented behaviors such as managing and appropriately expressing emotions, motivating employees, providing rewards for their satisfactory performance or attending to their needs [64,65]. Promoting cooperation and shared goals is also a particularly relevant challenge for leaders [26]. Consistent with these findings, companies may goodheartedly grow curious about "female advantage" proposals that female leaders display leadership styles associated with performance [2] and thus feel more motivated to implement gender equality.

Utilitarian viewpoints with emphasis on organizational effectiveness and the many potential benefits of gender equality in the organizational structure and climate may help to produce the necessary change within organizations. Companies' interests are often disconnected from social justice goals developed within public policies $[1,10,37]$, so putting together social sustainability and business interests is timely. Gender research has provided enough evidence to maintain that women are at least as good as men in terms of producing results for organizations, particularly in managerial positions $[17,66,67]$. Likewise, research has shown positive associations between the number of women on boards and relevant organizational functions, such as attending to stakeholders' needs $[68,69]$. If organizations can understand that these relational dimensions clash with traditional, stereotypically masculine gender roles, they may feel more motivated to successfully introduce gender equality actions and plans.

Companies may also become aware that information about gender equality influences organizational attractiveness and thus increases their interest in developing gender equality actions. In the current globalized context in which virtual information about companies' structures, including gender and diversity records, are easily accessible, companies' social sustainability and the situation of women can become important for their reputation [70,71]. Although meta-analytical reviews that have examined the effects of gender diversity on employees' performance have shown inconclusive effects [72-74], there is consistent and reliable evidence that female leaders perform more effectively in a wide range of communal leadership styles that are associated with positive responses from employees $[17,66,67]$. Therefore, promoting awareness about how gendered norms and stereotypes influence organizational life and decision-making should be a useful way of promoting gender equality through producing inner changes in managers' views about the issue.

An obvious concern is that solely focusing on business-related arguments leaves the relevant issue of social justice in the background. However, traditional social action in organizations has been criticized for lacking a theoretically-based and actionable framework for delivering sustainable programs that are aligned with organizational efforts and thus can clearly serve women's interests in organizations $[3,37]$. Therefore, broad commitments to social sustainability are important but not sufficient to truly implement change action, rendering necessary that managers and decision makers are fully convinced about the subtle and overt barriers that women and non-masculine values face in the organization's culture as well as their organizational effects so that they dedicate the necessary effort, resources and budget to gender equality action. It is also notable that managerial commitment is likely to be influenced more by psychological or personal factors than by cost-benefit issues $[75,76]$. Therefore, the inclusion of social justice arguments that promote not only profit-based utilitarian perspectives but also a more critical rethinking of gender relations in one's personal and organizational life seems critical. For instance, it is necessary to incorporate specific training that helps male and female managers become aware of their own stereotypes and general challenges with social justice, as well as how gender roles constrain their own personal and professional lives. Acknowledging the idea that solely underscoring a corporate case for gender equality can be dangerous, a tentative conclusion is that it is necessary to maintain a utilitarian social justice rationale for gender equality so that organizational practitioners are fully convinced about gender equality as an inviolable and necessary social right. 


\subsection{Evidence-Based Action}

A critical addition in our approach is that social sustainability actions should be guided by the necessary evidence-based knowledge to become truly effective in organizational practice. Obviously, there are many ways through which companies may develop a greater commitment to and reflective engagement in social sustainability based on scientific research. In the field of gender studies, a large amount of the research literature has identified an important and complex array of individual, interpersonal and organizational obstacles that women face in organizations, making it difficult to suggest simplistic actions with which women can rapidly advance to higher decision-making positions and opportunities for development $[2,51,66,77]$. Additionally, these issues may be controversial and challenging in organizational practice. Thus, one way in which a multi-agent evidence-based approach can extend its contribution is to examine the specific effects of the proposed interrelated actions, using objective measures of gender equality that capture actual social advancement in the organization (e.g., advancement of women to leadership positions or changes in gendered wages) as well as other direct and indirect indicators of organizational performance associated with such variables (e.g., changes in leadership styles, organizational values, economic performance or client reputation).

To respond to these goals, we note the general challenge of allocating more resources for scientific program evaluation. For instance, relevant institutions in the field of public health like the Working Group on Health Promotion Evaluation of the World Health Organization (WHO) recommend that around $10 \%$ of the total financial resources for a promotion initiative be allocated to evaluation [78]. To understand what causes a behavior or problem at work, it is important to gain an overall reliable portrait of when, why or by whom something occurs and to ask the appropriate diagnostic questions before acting so that the goals are set based on the specific situation that the organization is in. Such fact-gathering is a necessary antecedent of action, as it allows applying learned evidence and concepts appropriately and specifically to a situation, rather than centering decisions on someone's personal experience or more general facts about other organizations. Contrasting these challenges, systematic evaluations that include scientific reporting of information relevant to the process evaluation are rarely implemented $[79,80]$.

When performing evaluations, it is suggested that evaluators adhere to the highest technical standards [36], so gender and organizational researchers are particularly wellpositioned to respond to these technical challenges [81]. Advocates like policymakers or consultants have often been criticized because of their subjective orientations [52] (p. 1005), with studies pointing, in particular, to how gender consultants often fix on specific gender findings that support their positions without critical appraisals of how generalizable or scientifically valid their findings and actions are [82]. Acknowledging these concerns, we note that consulting companies are also relevant agents, providing training, advising and consultancy in daily applied action and evaluation in organizations. Thus, the generalized separation between consultancy firms and researchers can create problems in the practice, given that consultants-particularly those specialized and formally certified in a given domain of social sustainability - are in a unique position to put together utilitarian and social perspectives. Notably, these collaborations are scarce in practice [52], so the efforts made by the consulting and private firms of the collaborative practice presented here to incorporate academic expertise deserves special mention that can be simulated in future managerial practices. These collaborative programs can better integrate scientifically valid and appealing criteria, so we suggest that these strategic alliances generalize to other contexts in which social sustainability can be implemented.

\section{Discussion and Concluding Remarks}

Reducing women's workplace discrimination is recognized as a critical challenge for social justice and a potential source of competitive advantage in the business world. However, we still have little understanding about how to promote and leverage these interrelated objectives in practice. The most important contribution of the theory and 
collaborative practice presented here is offering a strong reminder that public institutions, gender researchers, consultants and management practitioners should work together to advance gender equality. Formal organizational policies, culture, processes and legislation can determine men and women's behavior through their key impact on social norms $[83,84]$. However, public policy that pushes companies to develop gender equality is not enough, with a growing imperative that gender issues go beyond legal prescriptions to produce structural and cultural changes in organizations and their managerial practices. Women's disadvantaged situation at work is to a great extent connected to companies' generalized lack of commitment towards gender equality, as well as common disconnections between social justice principles and firms' strategic goals [8,9]. Derived from and adding to these challenges, the theory and practice presented here underscored the relevance of putting together various organizational and societal actors to develop a strong system of multiagent cooperation, aimed at bringing new opportunities for the advancement of gender equality.

In summary, we argue that a strong regulatory framework, which provides the necessary pressure and resources to promote gender actions and is combined with a streamlined evidence-based rationale for the corporate case of gender equality, may be useful in the organizational practice of social sustainability. Balanced use of regulatory frameworks and attractive facts that increase firms' interest in gender equality, as well as comprehensive and nuanced evidence representative of the available scientific research, may be a useful strategy to increase private firms' actual commitment to gender equality in practice without compromising social justice. Through our cooperative framework, we suggest that advancement in this multi-dimensional and multi-disciplinary context can only be facilitated through the collaboration of different agents involved in the promotion of workplace gender equality. Such collaborative approaches can potentially allow a more successful combination of forces to fully develop gender equality plans in organizations.

An additional key insight of this multi-agent perspective is a reinvigorated view of research as a useful approach to gender management in practice. Traditional gender management approaches attempt to develop gender equality with generic repetitions of actions that are often imposed without critically appraising and imparting the ultimate function and scope of gender equality in organizations. Given these limitations in the promotion of gender equality, our article presented a cooperative action that might encourage further critical reflection on the topic. Ideally, this standpoint will serve to reconfigure our approach to gender management in organizations, shifting from individual to rigorous collaborative actions, transforming the view of gender equality as a social obligation that also needs to become central to strategic, organizational plans. We hope that these recommendations will prove useful in improving gender equality intervention and that other practitioners, researchers and gender policymakers will be able to use and test these foundations in future action and decision processes.

Funding: This research action received funding from The Gipuzkoa Provincial Council, Body for Equality of Women and Men, through the 2018 call for awards, "Experiencias en igualdad de mujeres y hombres» en empresas de Gipuzkoa". See https:/ / egoitza.gipuzkoa.eus/gao-bog/castell/bog/20 18/11/06/c1807323.pdf (accessed on 19 February 2021).

Institutional Review Board Statement: Not applicable.

Informed Consent Statement: Not applicable.

Data Availability Statement: Not applicable.

Acknowledgments: This work was supported by the Provincial Council of Gipuzkoa, Body for Equality of Women and Men, through the 2019 award for "Experiences in equality of women and men in companies in Gipuzkoa". I thank Aizpea Otaegi and Aizaga Zeberio (Elhuyar Foundation), as well as Nuria Agirre and Arrate Arcauz (Laboal Kutxa) for their generous assistance in revising the program content and providing the necessary information about Laboral Kutxa to be included in this manuscript. 
Conflicts of Interest: The authors declare no conflict of interest.

\section{Appendix A}

Table A1. Syllabus for an evidence-based training session linking gender and empowerment.

\begin{tabular}{|c|c|c|c|c|}
\hline SUBJECT & AIM & PROCEDURE & RESOURCES & $\begin{array}{l}\text { TIME } \\
(\min )\end{array}$ \\
\hline \multirow[t]{2}{*}{ Introduction } & \multirow{2}{*}{$\begin{array}{l}\text { Contextualize the } \\
\text { meeting and } \\
\text { present the topics } \\
\text { to be discussed }\end{array}$} & $\begin{array}{l}\text { Agreement on the language of the meeting. } \\
\text { Introducing the gender researcher and the participants of the } \\
\text { commission. Members explain who they are, the position they } \\
\text { hold and an unknown hobby. } \\
\text { - Contextualization of the meeting. }\end{array}$ & \multirow{2}{*}{$\begin{array}{l}\text { PowerPoint } \\
\text { presentation }\end{array}$} & \multirow[t]{2}{*}{15} \\
\hline & & $\begin{array}{l}\text { The meeting agenda is presented: } \\
\text { - } \quad \text { Scientific introduction to the concept of empowerment. } \\
\text { - } \quad \text { Identification of evidence-based areas of improvement. } \\
\text { Assessment of the meeting. }\end{array}$ & & \\
\hline $\begin{array}{l}\text { Scientific } \\
\text { introduction to } \\
\text { gender and } \\
\text { empowerment }\end{array}$ & $\begin{array}{l}\text { Theoretical } \\
\text { approach to } \\
\text { empowerment }\end{array}$ & $\begin{array}{l}\text { Evidence-based explanation of the academic theoretical framework by } \\
\text { the gender researcher }\end{array}$ & $\begin{array}{l}\text { PowerPoint } \\
\text { presentation }\end{array}$ & 45 \\
\hline
\end{tabular}

Evidence-based improvement areas
Identification of three main areas of improvement.
- $\quad$ Taking as a reference the concepts and scientific evidence provided by the gender researcher, each person prioritizes three lines of work. For this, we give each person three Post-It notes and ask them to write each line of work in one of them (individual work).

- $\quad$ Three workgroups are created, giving out different colored sweets. People are grouped based on the flavor of the sweet they have chosen.

- $\quad$ Once the groups are created, each member explains his/her prioritized areas; afterward, groups have to likewise identify the most important common areas guided by the gender experts.

- They describe each area on a colored sheet of paper (teamwork).

- The colored sheets of paper are placed on the flip chart, to be located on each of the three main dimensions of empowerment (structural, individual, social/relational), guided by the gender experts.

- $\quad$ Three stickers are given, which have to be placed on the areas that members consider most appropriate.

- $\quad$ Participants comment on the areas of improvement that received most support (group work).
Post-It

Colored Sheets of Paper

Photographs Pens

Markers

Flip Chart

Adhesive Tape

Stickers

Sweets

- We form three different groups taking into account each person's preferences for the proposed areas, with a balanced number of people per group.

- $\quad$ Each group has to fill out a data sheet with the following contents:

Development of the specific areas of work
Define each line of work
Area of work.

What is the situation?

Goal: What do we want to achieve? (objectives)

Route: How will we achieve it? (methodology)

Traveling partners: Who would need to participate?

Evaluation: How will we know if the proposal has been completed?

- $\quad$ Once the data-sheet is filled out, groups share their ideas and receive feedback from the gender facilitators.

$\begin{array}{ll}\begin{array}{l}\text { Assessment of the } \\ \text { meeting }\end{array} & \begin{array}{l}\text { Assess the } \\ \text { meeting }\end{array}\end{array}$

- Participants choose a role model and explain why they have chosen her/him, following a discussion from a gender perspective guided by the gender experts.

- $\quad$ Finally, participants respond to a short assessment about the program contents, design and structure. 


\section{Appendix B}

Table A2. Sample file of a group dynamic to translate evidence-based learning into action.

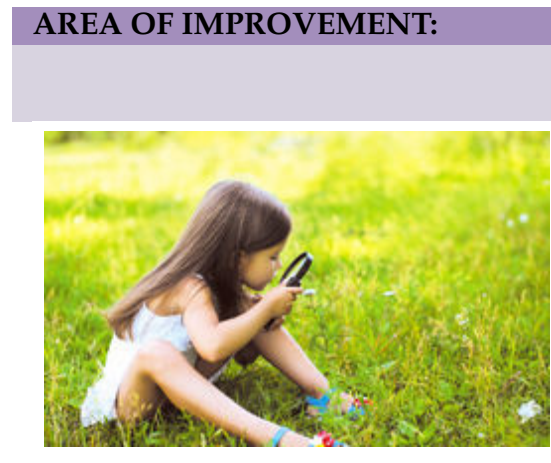

INITIAL SITUATION: WHY IS IT IMPORTANT? WHAT IS THE CURRENT SITUATION?

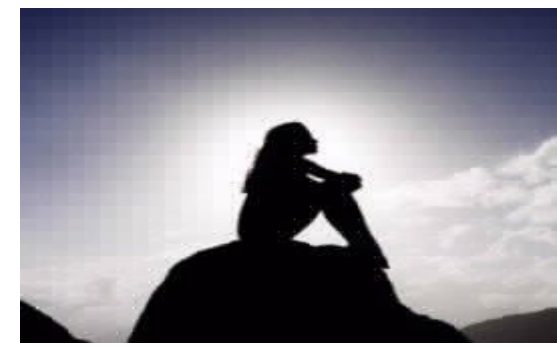

GOAL: WHAT DO WE WANT TO ACHIEVE? (OBJECTIVES)

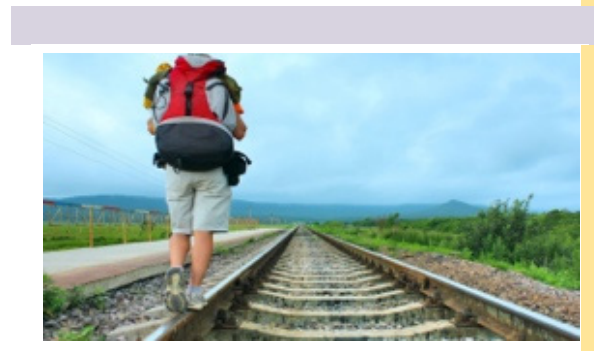

ROUTE: HOW WILL WE ACHIEVE IT? (METHODOLOGY)

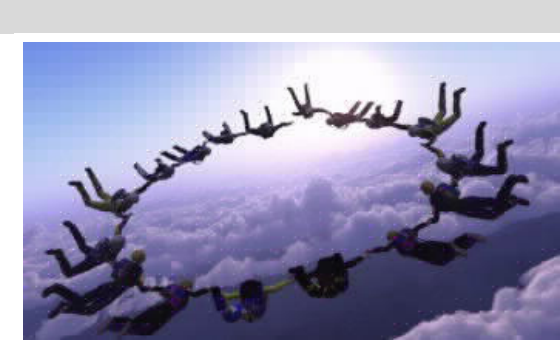

TRAVELLING PARTNERS: WHO SHOULD PARTICIPATE?

EVALUATION: HOW WILL WE KNOW IF GOALS WERE ACHIEVED?

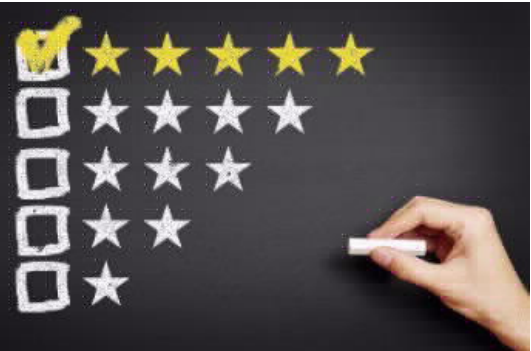


Appendix C

Table A3. Summary of actions to be implemented in the Basque company at stage one of the three levels of empowerment (structural, individual, social/relational).

\begin{tabular}{|c|c|c|c|c|}
\hline \multicolumn{5}{|c|}{ DIMENSION 1: STRUCTURAL EMPOWERMENT } \\
\hline $\begin{array}{l}\text { STARTING POINT: WHY IS IT } \\
\text { IMPORTANT AND WHAT IS THE } \\
\text { CURRENT SITUATION? }\end{array}$ & $\begin{array}{c}\text { GOAL: WHAT DO WE WANT } \\
\text { TO ACHIEVE? }\end{array}$ & $\begin{array}{c}\text { ROUTE: HOW WILL IT BE } \\
\text { ACHIEVED? }\end{array}$ & $\begin{array}{l}\text { TRAVEL PARTNERS: WHO } \\
\text { SHOULD PARTICIPATE? }\end{array}$ & $\begin{array}{l}\text { EVALUATION: HOW WILL WE } \\
\text { KNOW IF GOALS WERE } \\
\text { ACHIEVED? }\end{array}$ \\
\hline
\end{tabular}

Situation:

Office directors do not use work-life

balance measures. People who manage

teams must be present at work; they

cannot work part-time (company

culture). It will have to be shown that

using work-life balance measures has

no penalty (because at present there is

no real availability).

Opportunity:

Could give value to the work post.

People who occupy posts of

responsibility manage teams. Could

they delegate some work? Could they

manage the teams having a reduced

working day?

\section{Situation:}

Most competencies and definitions of

job positions are based on agentic,

stereotypically masculine profiles,

which gives rise to discriminatory

recruitment/promotion processes for

women.

Opportunity:

REDEFINE PROFILES OF JOB

POSITIONS (lessen agentic

A review of competencies towards

softer, more humanistic profiles that go

beyond traditional male-dominated

profiles and skills and are more in line

with contemporary challenges.

ideals)
Participatory process to gather opinions.

Carry out innovative reflection on

existing work-life balance measures

INCREASE MANAGERS' USE at the present time.

OF WORK-LIFE BALANCE

MEASURES

Applying a win-win perspective,

based on the idea that the program

can also be positive for the company;

this will also help motivate people

in managerial positions to get

involved in gender issues.
-Indicator 1: Number of applications and actual use of work-life balance measures by people in managerial positions (including pre-and post-evaluation)

Gender Equality Coordinator and HR Department

-Indicator 2: Number of applications and actual use of work-life balance measures in general.

-Indicator 3: Measure of the subjective experiences of workers (pre and post).

Review the catalog of competencies and capacities and the definition of job profiles

Department of Social

Management and Equality

Commission

All staf
-Indicator 1: Report/analysis on the composition of managerial positions in relation to agentic, "masculine" features -Indicator 2: Report of proposals abou how to include communal values and competencies in the definition of job positions (e.g., revised competence profile). 
Table A3. Cont.

\section{Situation:}

A specific mentoring role was created to make re-adaptation and promotion after an absence easier (relevant for women and after leave periods); however, this role was not being successfully

developed.

\section{Situation:}

A need to generate awareness and reduce gender stereotypes among all employees.

\section{IMPROVE PROCESSES OF RETURNING TO WORK} AFTER ABSENCE
Resume and review the figure of the mentor and its connections with promotion processes.

Establish a period of training and adaptation specifically for the first few days after returning to work.
-Indicator 1: No reversals in the system of managing the task after re-joining. -Indicator 2: Number of women promoted to positions of responsibility after an absence.

-Indicator: Number of persons trained at different levels of intensification (pre and post).

\section{DIMENSION 2: INDIVIDUAL EMPOWERMENT}

STARTING POINT: WHY IS IT IMPORTANT AND WHAT IS THE CURRENT SITUATION?

Situation:
The individual elements/values that
hinder involvement in equality are not
known.
Situation:
It is necessary to develop individual
awareness and personal involvement of
men and women on equality (open to
different degrees of intensification).

different degrees of intensification).
Offer training and

awareness-raising at different levels All staff

of intensification
In process

\section{GOAL: WHAT DO WE WANT} TO ACHIEVE?
AWARENESS RAISING AND UNDERTAKE EVALUATION

DIAGNOSIS Specific

objectives:

- Identify personal elements that

hinder empowerment and

access of women to positions of management.

- Analyze the level of

commitment to the diagnosis

and gender equality plan

(examine levels of acceptance).

\section{ACTIONS OF INDIVIDUAL}

AWARENESS
ROUTE: HOW WILL IT BE ACHIEVED?

\section{TRAVEL PARTNERS: WHO SHOULD PARTICIPATE?}

\section{EVALUATION: HOW WILL WE
KNOW IF GOALS WERE} ACHIEVED?
Design and pass out a questionnaire with validated scales.

Carry out focus groups with key

informants (whistle-blowers).
Questionnaire: All staff. Focus Group: Representative sample (employees with different levels of awareness).
-Indicator 1: Design and dissemination of questionnaire (including the number of responses).

-Indicator 2: Creation of focus group.

\section{Use the diagnosis as a tool for} reflection

Undertaking training in conceptual analysis of gender empowerment at three levels of analysis (Level 1: basic online; Level 2: in person; Level 3: advanced).
Level 1: online information (all staff).

Level 2: face-to-face session (priority sectors/volunteers) Level 3: to be specified (via Social Council, Social

Management, Management). 
Table A3. Cont.

\begin{tabular}{|c|c|c|c|c|}
\hline $\begin{array}{l}\text { Situation: } \\
\text { It is necessary to reach out to other } \\
\text { people in the company and create a } \\
\text { more extensive network of people } \\
\text { involved in empowerment. }\end{array}$ & $\begin{array}{l}\text { CREATION OF A DRIVING } \\
\text { GROUP (to serve as a reference } \\
\text { to be able to reach out to a } \\
\text { greater number with a } \\
\text { multiplier effect) }\end{array}$ & $\begin{array}{l}\text { Identify people interested in the } \\
\text { theme through training and } \\
\text { awareness (people will be identified } \\
\text { in the sessions). }\end{array}$ & $\begin{array}{l}\text { People interested, women and } \\
\text { men (10-15 people identified } \\
\text { from the awareness-raising } \\
\text { actions). }\end{array}$ & -Indicator: Creation of the group. \\
\hline \multicolumn{5}{|c|}{ DIMENSION 3: SOCIAL/RELATIONAL EMPOWERMENT } \\
\hline $\begin{array}{c}\text { STARTING POINT: WHY IS IT } \\
\text { IMPORTANT AND WHAT IS THE } \\
\text { CURRENT SITUATION? }\end{array}$ & $\begin{array}{c}\text { GOAL: WHAT DO WE WANT } \\
\text { TO ACHIEVE? }\end{array}$ & $\begin{array}{l}\text { ROUTE: HOW WILL IT BE } \\
\text { ACHIEVED? }\end{array}$ & $\begin{array}{l}\text { TRAVEL PARTNERS: WHO } \\
\text { SHOULD PARTICIPATE? }\end{array}$ & $\begin{array}{l}\text { EVALUATION: HOW WILL WE } \\
\text { KNOW IF GOALS WERE } \\
\text { ACHIEVED? }\end{array}$ \\
\hline $\begin{array}{l}\text { Situation: } \\
\text { Greater need to portray the firm as an } \\
\text { organization committed to equality } \\
\text { (internally and externally). }\end{array}$ & $\begin{array}{l}\text { REINFORCE } \\
\text { INSTITUTIONAL IMAGE OF } \\
\text { COMMITMENT TO } \\
\text { EQUALITY }\end{array}$ & $\begin{array}{l}\text { Place more women in public events, } \\
\text { communication acts, representation } \\
\text { of female leaders in all meetings, etc. } \\
\text { Incorporate more explicit } \\
\text { "communal" } \\
\text { values/expectations/interests. } \\
\text { Put more emphasis on equality } \\
\text { being informally and } \\
\text { organizationally appreciated. } \\
\text { Establish common guidelines }\end{array}$ & $\begin{array}{l}\text { Women at any level (following } \\
\text { guidelines) }\end{array}$ & $\begin{array}{l}\text {-Indicator 1: Number of women who } \\
\text { have participated in the initiatives } \\
\text {-Indicator 2: Measurements via } \\
\text { customer surveys }\end{array}$ \\
\hline
\end{tabular}


Table A3. Cont.

\section{Situation:}

Need to create more virtual and in-person spaces to discuss issues of gender equality, exchange ideas and increase the number of employees involved in gender issues (to reinforce collective consciousness and relevance given to the topic).
PROMOTE CRITICAL SPACES OF PARTICIPATION AND EXCHANGE OF IDEAS

\section{Situation:}

Low Social/Collective awareness

\section{CREATE COLLECTIVE \\ AWARENESS VIA}

REFLECTION
Create an identifiable and flexible

network (such as the Basque

network "Sarea").

Use the existing network to provide

information about the

Empowerment program and gender

equality plans.

Create a leading group that ensures People who make up the

activity in the network and

organizes campaigns (identify

people with awareness via the

actions planned in the dimension of

network or driving-force group

(at different hierarchical levels)

Gender Equality Coordinator

individual change); Give the

network or driving-force group a

name.

Open call to people interested in

participating using existing

resources (Giltzanet, Work portal).

Launch one or two questions to all

staff (What can I do in favor of

equality?) Online question

accompanied by an

awareness-raising video performed Equality Commission

by actual employees.

Create a Decalogue of undertakings

Organize a public event to share

conclusions and strengths

collectively and raise awareness

among people inside and outside

the organization, including relations

with other companies. (organizer)

Participants: volunteers for the

videos.

Open to everyone.
-Indicator 1: Creation of the

action-driven group.

-Indicator 2: Number of Initiatives

carried out by the driving-force group

-Indicator 3: Number of employees who

participate in (1) the leading group, and

(2) the forum and online discussions.
-Indicator 1: Number of replies received.

-Indicator 2: Measurement of increased awareness via the diagnosis.

-Indicator 1: Impact of the event, attendance, media coverage.

* This action overlaped with the individual dimension of empowerment; it was considered at the structural level to create common norms and culture. 


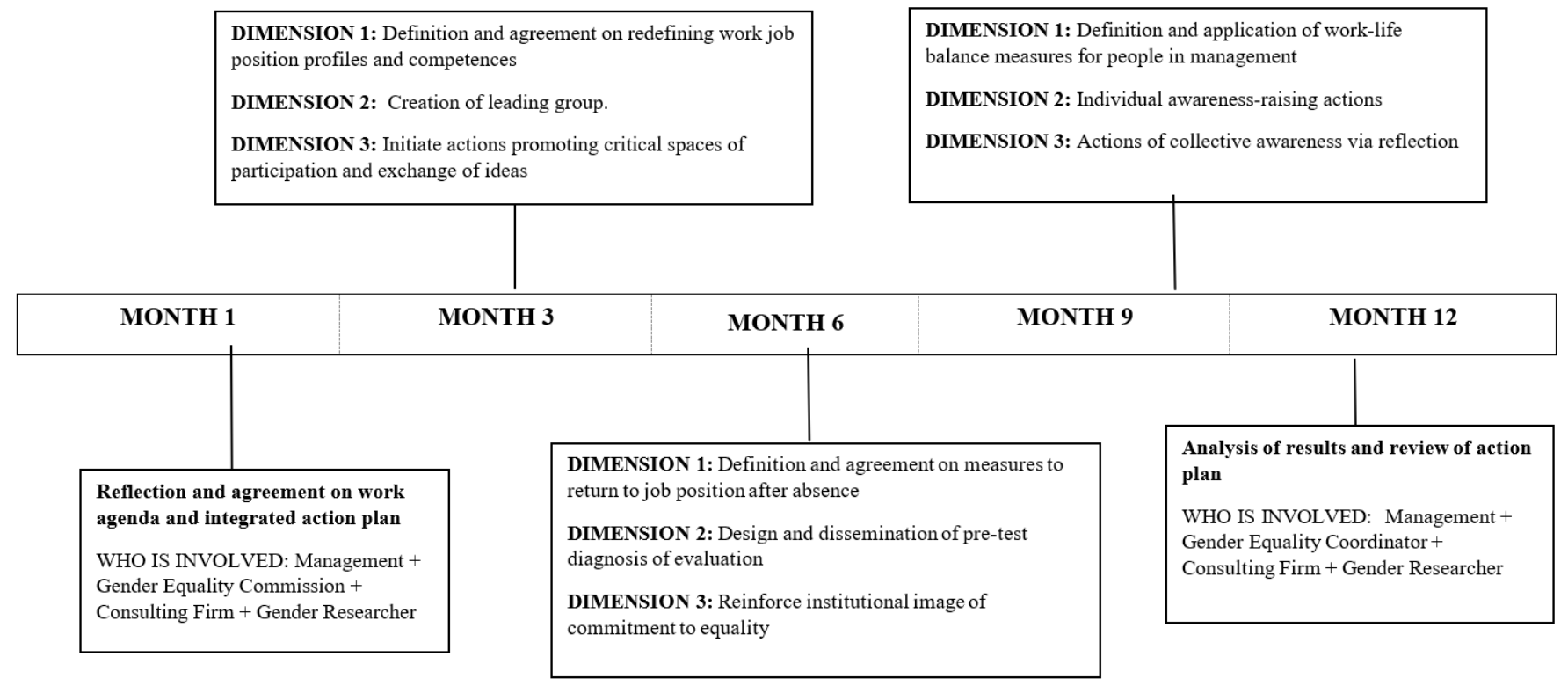

Figure A1. Work plan schedule.

\section{References}

1. Thomas, D.; Kai, H. Beyond the Business Case for Corporate Sustainability. Bus. Strategy Environ. 2002, 11, 130-141.

2. Eagly, A.H.; Gartzia, L.; Carli, L.L. Female Advantage. In The Oxford Handbook of Gender in Organizations; Kumra, S., Simpson, R., Burke, R., Eds.; Oxford University Press: Oxford, UK, 2004; pp. 153-166.

3. Ely, R.J.; Ibarra, H.; Kolb, D.M. Taking Gender into Account: Theory and Design for Women's Leadership Development Programs. Acad. Manag. Learn. Educ. 2011, 10, 474-493. [CrossRef]

4. United Nations. Sustainable Development Goals. Goal 5: Achieve Gender Equality and Empower all Women and Girls. Available online: http:/ / www.un.org/sustainabledevelopment/gender-equality/ (accessed on 19 February 2021).

5. European Commission. Strategic Engagement for Gender Equality 2016-2019. Available online: http:/ / ec.europa.eu/justice/ gender-equality/document/files/strategic_engagement_en (accessed on 19 February 2021).

6. Hausmann, R.; Hidalgo, C.A.; Bustos, S.; Coscia, M.; Simoes, A.; Yildirim, M.A. The Atlas of Economic Complexity: Mapping Paths to Prosperity; MIT Press: Cambridge, MA, USA, 2014.

7. World Economic Forum. Global Gender Gap Report. Available online: http://www3.weforum.org/docs/WEF_GGGR_2020.pdf (accessed on 19 February 2021).

8. Grosser, K.; Moon, J. Developments in company reporting on workplace gender equality? Account. Forum. 2008, 32, 179-198. [CrossRef]

9. Pfau-Effinger, B. Socio-historical paths of the male breadwinner model—an explanation of cross-national differences. Br. J. Sociol. 2004, 55, 377-399. [CrossRef] [PubMed]

10. Martin, J.; Meyerson, D. Women and Power: Conformity, Resistance, and Disorganized Co-Action. Power and Influence in Organizations; SAGE Publications: Thousand Oaks, CA, USA, 1998; pp. 311-348.

11. Adams, R.B. Women on boards: The superheroes of tomorrow? Leadersh. Q. 2016, 27, 371-386. [CrossRef]

12. Acker, J. From glass ceiling to inequality regimes. Sociol. Trav. 2009, 51, 199-217. [CrossRef]

13. Nielsen, S.; Huse, M. The Contribution of Women on Boards of Directors: Going beyond the Surface. Corp. Governance Int. Rev. 2010, 18, 136-148. [CrossRef]

14. Ridgeway, C.L. Framed by Gender: How Gender Inequality Persists in the Modern World; Oxford University Press: Oxford, UK, 2011.

15. Stafsudd, A. People are strange when you're a stranger: Senior executives select similar successors. Eur. Manag. Rev. 2006, 3, 177-189. [CrossRef]

16. Koenig, A.M.; Eagly, A.H.; Mitchell, A.A.; Ristikari, T. Are leader stereotypes masculine? A meta-analysis of three research paradigms. Psychol. Bull. 2011, 137, 616-642. [CrossRef] [PubMed]

17. Eagly, A.H.; Karau, S.J.; Makhijani, M.G. Gender and the effectiveness of leaders: A meta-analysis. Psychol. Bull. 1995, 117, 125-145. [CrossRef] [PubMed]

18. Stewart, M.B. Why is the Gender Pay Gap Higher in the Private Sector? 2014. Available online: https://warwick.ac.uk/fac/soc/ economics/staff/mstewart/gender_pay_gap_in_private_sector.pdf (accessed on 19 February 2021).

19. Forcadell, F.J. Democracia, cooperación y éxito: Implicaciones prácticas del caso de Mondragón. Universia Bus. Rev. 2005, 6, 54-67. 
20. Haveman, H.A.; Russo, M.V.; Meyer, A.D. Organizational environments in flux: The impact of regulatory punctuations on organizational domains, CEO secession, and performance. Organ. Sci. 2001, 12, 153-273. [CrossRef]

21. European Commission. Gender Equality. Available online: https://ec.europa.eu/info/strategy/justice-and-fundamental-rights/ discrimination/gender-equality_en) (accessed on 19 February 2021).

22. Iceland Ministry of Social Affairs. Act on Equal Status and Equal Rights of Women and Men No. 10/2008. Available online: https: / www.government.is/library/04-Legislation/Act $\% 20$ on $\% 20$ equal $\% 20$ status $\% 20$ and $\% 20$ equal $\% 20$ rights $\% 20$ of $\% 20$ women\%20and\%20men\%20no\%2010\%202008\%20as\%20amended\%200101\%202018\%20final.pdf (accessed on 19 February 2021).

23. Martínez-Sánchez, J.M.; Fernández, E.; Fu, M.; Gallus, S.; Martínez, C.; Sureda, X.; La Vecchia, C.; Clancy, L. Smoking Behaviour, Involuntary Smoking, Attitudes towards Smoke-Free Legislations, and Tobacco Control Activities in the European Union. PLoS ONE 2010, 5, e13881. [CrossRef]

24. Nastasi, B. Meeting the Challenges of the Future: Integrating Public Health and Public Education for Mental Health Promotion. J. Educ. Psychol. Consult. 2004, 15, 295-312. [CrossRef]

25. Gartzia, L.; Van Engen, M. Are (male) leaders "feminine" enough? Gend. Manag. Int. J. 2012, 27, 296-314. [CrossRef]

26. Gartzia, L.; van Knippenberg, D. Too Masculine, Too Bad. Group Organ. Manag. 2016, 41, 458-490. [CrossRef]

27. Bustelo, M. Three Decades of State Feminism and Gender Equality Policies in Multi-governed Spain. Sex Roles 2014, 74, 107-120. [CrossRef]

28. Gartzia, L.; Pizarro, J. Gender and Leadership in Higher Education and Research: Institutional Challenges and Resistances; European Commission (GEARING-ROLES project): Brussels, Belgium, 2021.

29. Reuters. Women in Senior Management Stagnant in Corporate Spain at only 16\%. Available online: https://www.reuters.com/ article/us-spain-women-companies-idINKBN2492QF (accessed on 19 February 2021).

30. Eustat. The Basque Country is in Fifth Place in the Gender Equality Index Ranking of the Countries of the European Union. Available online: http://en.eustat.eus/elementos/ele0013400/ti_The_Basque_Country_is_in_fifth_place_in_the_Gender_Equality_ Index_ranking_of_the_countries_of_the_European_Union/not0013407_i.html (accessed on 19 February 2021).

31. Eustat. The Gender Equality Index of the Basque Country Improved for Another Year Running to Stand at 71.1 Points Out of 100. Available online: https:/ / en.eustat.eus/elementos/the-gender-equality-index-of-the-basque-country-improved-for-anotheryear-running-to-stand-at-711-points-out-of-100/not0017325_i.html (accessed on 19 February 2021).

32. EIGE (European Institute for Gender Equality). Gender Impact Assessment, Basque Country. Available online: http:/ / eige. europa.eu/gender-mainstreaming/toolkits/gender-impact-assessment/basque-country (accessed on 19 February 2021).

33. Emakunde, Gizonduz, Emakunde, Basque Institute for Women, March. Available online: https: / www.emakunde.euskadi.eus / gizoncas/- /informacion/gizonduz-intro/ (accessed on 19 February 2021).

34. Whelan-Berry, K.S.; Somerville, K.A. Linking change drivers and the organizational change process: A review and synthesis. J. Change. Manag. 2010, 10, 175-193. [CrossRef]

35. Kotter, J.P. A Sense of Urgency; Harvard Business Press: Boston, MA, USA, 2008.

36. American Management Association. Survey on Change Management; AMA: New York City, NY, USA, 1994.

37. Gill, R. Change management-or change leadership? J. Change Manag. 2002, 3, 307-318. [CrossRef]

38. European Institute for Gender Equality. Gender equality in research and Academia. Available online: https: / / eige.europa.eu/ gender-mainstreaming/toolkits/gear/what-gender-equality-plan-gep (accessed on 19 February 2021).

39. Judge, T.A.; Bono, J.E. Relationship of core self-evaluations traits-self-esteem, generalized self-efficacy, locus of control, and emotional stability—with job satisfaction and job performance: A meta-analysis. J. Appl. Psychol. 2001, 86, 80-92. [CrossRef]

40. Ragins, B.R.; Townsend, B.; Mattis, M. Gender gap in the executive suite: CEOs and female executives report on breaking the glass ceiling. Acad. Manag. Perspect. 1998, 12, 28-42. [CrossRef]

41. Rousseau, D.M.; McCarthy, S. Educating Managers From an Evidence-Based Perspective. Acad. Manag. Learn. Educ. 2007, 6, 84-101. [CrossRef]

42. Euskalit. La Igualdad está Llena de Pequeños Detalles. Corto Finalista de la 1. edición Gestión en Corto Sobre Diferentes Sketches que nos Hacen Reflexionar Sobre la Desigualdad y la Igualdad [Video]. Available online: https://www.youtube.com/watch?v= a4OZ62Jbvrc\&index=4\&list=PLkfXSeRqY3INlf7CTk480j-3XcfEUvofo (accessed on 19 February 2021).

43. Scott, C.D.; Jaffe, D.T. Survive and thrive in times of change. Train. Dev. J. 1988, 42, 25.

44. Hirschhorn, L. Campaigning for change. Harv. Bus. Rev. 2002, 80, 98-104.

45. Knodel, T. Preparing the organizational 'soil' for measurable and sustainable change: Business value manage-ment and project governance. J. Change Manag. 2004, 4, 45-62. [CrossRef]

46. Weick, K.E.; Quinn, R.E. Organizational Change and Development. Annu. Rev. Psychol. 1999, 50, 361-386. [CrossRef]

47. Dumas, J.E.; Prinz, R.J.; Smith, E.P.; Laughlin, J. The EARLY ALLIANCE prevention trial: An integrated set of interventions to promote competence and reduce risk for conduct disorder, substance abuse, and school failure. Clin. Child. Fam. Psychol. Rev. 1999, 2, 53. [CrossRef] [PubMed]

48. Varjas, K.; Meyers, J.; Henrich, C.; Graybill, E.; Dew, B.; Marshall, M.; Williamson, Z.; Skoczylas, R.; Avant, M. Using a Participatory Culture-Specific Intervention Model to De-velop a Peer Victimization Intervention. J. Appl. Sch. Psychol. 2006, 22, 35-57. [CrossRef]

49. Lüscher, L.S.; Lewis, M.W. Organizational Change and Managerial Sensemaking: Working Through Paradox. Acad. Manag. J. 2008, 51, 221-240. [CrossRef] 
50. Eden, C.; Huxman, C. Action Research for Management Research. Br. J. Manag. 1996, 7, 75-86. [CrossRef]

51. Eagly, A.H. From social psychology to the theory and practice of conflict resolution. Peace Confl. J. Peace Psychol. 2017, 23, 199-200. [CrossRef]

52. Alvesson, M. Organizations as Rhetoric Knowledge-Intensive Firms and the Struggle with Ambiguity. J. Manag. Stud. 1993, 30, 997-1015. [CrossRef]

53. Haley, U.C.; Champion, P.; Page, M.C.; Pitsis, T.S.; Rivas, J.L.; Yu, K.F. Measuring and Achieving Scholarly Impact: A Report from the Academy of Management's Practice Theme Committee; ResearchGate Company: Berlin, Germany, 2007.

54. Matt, G.E.; Cook, T.D. Threats to the Validity of Generalized Inferences from Research Syntheses. In The Handbook of Research Synthesis and Meta-Analysis; Russell Sage Foundation: New York, NY, USA, 2019; pp. 489-516.

55. Zimmerman, M.A.; Rappaport, J. Citizen participation, perceived control, and psychological empowerment. Am. J. Community Psychol. 1988, 16, 725-750. [CrossRef] [PubMed]

56. Peterson, R.D.; Grippo, K.P.; Tantleff-Dunn, S. Empowerment and Powerlessness: A Closer Look at the Relationship Between Feminism, Body Image and Eating Disturbance. Sex Roles 2008, 58, 639-648. [CrossRef]

57. Spreitzer, G.M. Giving peace a chance: Organizational leadership, empowerment, and peace. J. Organ. Behav. 2007, 28, 1077-1095. [CrossRef]

58. Conger, J.A.; Kanungo, R.N. The empowerment process: Integrating theory and practice. Acad. Manag. Rev. 1988, 13, 471-482. [CrossRef]

59. Thomas, K.W.; Velthouse, B.A. Cognitive elements of empowerment: An "interpretive" model. Acad. Manag. Rev. 1990, 15, 666-681.

60. Glynn, T.J. Psychological Sense of Community: Measurement and Application. Hum. Relat. 1981, 34, 789-818. [CrossRef]

61. Rappaport, J.; Reischl, T.; Zimmerman, M. Mutual help mechanisms in the empowerment of former men-tal patients. In The Strengths Perspective in Social Work Practice, White Plains; Saleebey, D., Ed.; Longman: London, UK, 1992.

62. Sarason, S.B. The Psychological Sense of Community: Prospects for a Community Psychology; Jossey-Bass: San Francisco, CA, USA, 1974.

63. Latham, G.P.; Locke, E.A. Goal setting-A motivational technique that works. Organ. Dyn. 1979, 8, 68-80. [CrossRef]

64. Avolio, B.J.; Walumbwa, F.O.; Weber, T.J. Leadership: Current Theories, Research, and Future Directions. Annu. Rev. Psychol. 2009, 60, 421-449. [CrossRef]

65. Bass, B.M.; Riggio, R.E. Transformational Leadership; Routledge: London, UK, 2006.

66. Eagly, A.H.; Johannesen-Schmidt, M.C.; Van Engen, M.L. Transformational, transactional, and laissez-faire leadership styles: A meta-analysis comparing women and men. Psychol. Bull. 2003, 129, 569-591. [CrossRef]

67. Eagly, A.H.; Johnson, B.T. Gender and leadership style: A meta-analysis. Psychol. Bull. 1990, 108, 233-256. [CrossRef]

68. Harjoto, M.; Laksmana, I.; Lee, R. Board Diversity and Corporate Social Responsibility. J. Bus. Ethics 2015, 132, 641-660. [CrossRef]

69. Boulouta, I. Hidden connections: The link between board gender diversity and corporate social performance. J. Bus. Ethics 2013, 113, 185-197. [CrossRef]

70. Bear, S.; Rahman, N.; Post, C. The Impact of Board Diversity and Gender Composition on Corporate Social Responsibility and Firm Reputation. J. Bus. Ethic. 2010, 97, 207-221. [CrossRef]

71. Bernardi, A.R.; Bosco, S.M.; Columb, V.L. Does Female Representation on Boards of Directors Associate with the 'Most Ethical Companies' List? Corp. Reput. Rev. 2009, 12, 270-280. [CrossRef]

72. Horwitz, S.K.; Horwitz, I.B. The Effects of Team Diversity on Team Outcomes: A Meta-Analytic Review of Team Demography. J. Manag. 2007, 33, 987-1015. [CrossRef]

73. Emory, C. Women Rising: The Unseen Barriers. CFA Dig. 2013, 43, 60-66. [CrossRef]

74. Joshi, A.; Roh, H. The Role of Context in Work Team Diversity Research: A Meta-Analytic Review. Acad. Manag. J. 2009, 52, 599-627. [CrossRef]

75. Stevens, J.M.; Beyer, J.M.; Trice, H.M. Assessing Personal, Role, and Organizational Predictors of Managerial Commitment. Acad. Manag. J. 1978, 21, 380-396. [CrossRef]

76. Taylor, K. The New Case for Women on Corporate Boards: New perspectives, Increased Profits. Forbes, 26 June 2012. Available online: http:/ / www.forbes.com/sites/katetaylor/2012/a.06/26/the-new-case-for-women-on-corporate-boards-new-perspectivesincreased-profits / (accessed on 19 February 2021).

77. Eagly, A. Women and the labyrinth of leadership. Hum. Resour. Manag. Int. Dig. 2008, 16. [CrossRef]

78. CDC (Centers for Disease Control and Pre-vention). Program Performance and Evaluation Office (PPEO). Available online: https:/ / www.cdc.gov/eval/guide/introduction/index.htm\#ftn7 (accessed on 19 February 2021).

79. Bouffard, A.J.; Taxman, F.S.; Silverman, R. Improving process evaluations of correctional programs by using a comprehensive evaluation methodology. Evaluation Program Plan. 2003, 26, 149-161. [CrossRef]

80. Murta, S.G.; Sanderson, K.; Oldenburg, B. Process Evaluation in Occupational Stress Management Programs: A Systematic Review. Am. J. Heal. Promot. 2007, 21, 248-254. [CrossRef] [PubMed]

81. Eagly, A.H. Sex differences in social behavior: Comparing social role theory and evolutionary psychology. Am. Psychol. 1997, 52, 1380-1383. [CrossRef]

82. Eagly, A.H. Reporting sex differences. Am. Psychol. 1987, 42, 756-757. [CrossRef] 
83. Boeri, T.; Del Boca, D.; Pissarides, C.A. (Eds.) Women at work: An Economic Perspective; Oxford University Press: Oxford, UK, 2005.

84. Lewis, C.; Koyasu, M.; Oh, S.; Ogawa, A.; Short, B.; Huang, Z. Culture, executive function, and social understanding. New Dir. Child Adolesc. Dev. 2009, 2009, 69-85. [CrossRef] [PubMed] 